\title{
An assessment of human resource distribution for public eye health services in KwaZulu-Natal, South Africa
}

\begin{tabular}{|c|c|}
\hline \multicolumn{2}{|c|}{$\begin{array}{l}\text { Authors: } \\
\text { Zamadonda N. Xulu-Kasaba }{ }^{1} \\
\text { Khathutshelo P. Mashige }^{1} \\
\text { Kovin S. Naidoo } \\
\end{array}$} \\
\hline \multicolumn{2}{|c|}{$\begin{array}{l}\text { Affiliations: } \\
\text { }{ }^{1} \text { Discipline of Optometry, } \\
\text { School of Health Sciences, } \\
\text { University of KwaZulu-Natal, } \\
\text { Durban, South Africa }\end{array}$} \\
\hline \multicolumn{2}{|c|}{$\begin{array}{l}{ }^{2} \text { Department of Optometry, } \\
\text { University of New South } \\
\text { Wales, Sydney, Australia }\end{array}$} \\
\hline \multicolumn{2}{|c|}{$\begin{array}{l}\text { Corresponding author: } \\
\text { Zamadonda Xulu-Kasaba, } \\
\text { xulukasabaz@ukzn.ac.za }\end{array}$} \\
\hline \multicolumn{2}{|c|}{$\begin{array}{l}\text { Dates: } \\
\text { Received: } 11 \text { June } 2020 \\
\text { Accepted: } 04 \text { Apr. } 2021 \\
\text { Published: } 07 \text { June } 2021\end{array}$} \\
\hline \multicolumn{2}{|c|}{$\begin{array}{l}\text { How to cite this article: } \\
\text { Xulu-Kasaba ZN, Mashige KP, } \\
\text { Naidoo KS. An assessment of } \\
\text { human resource distribution } \\
\text { for public eye health services } \\
\text { in KwaZulu-Natal, South } \\
\text { Africa. Afr Vision Eye Health. } \\
\text { 2021;80(1), a583. https://doi. } \\
\text { org/10.4102/aveh.v80i1.583 }\end{array}$} \\
\hline \multicolumn{2}{|c|}{$\begin{array}{l}\text { Copyright: } \\
\text { (c) 2021. The Author(s). } \\
\text { Licensee: AOSIS. This w } \\
\text { is licensed under the } \\
\text { Creative Commons } \\
\text { Attribution License. }\end{array}$} \\
\hline \multicolumn{2}{|l|}{ Read online: } \\
\hline 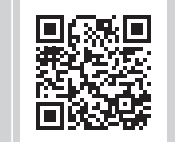 & $\begin{array}{l}\text { Scan this QR } \\
\text { code with your } \\
\text { smart phone or } \\
\text { mobile device } \\
\text { to read online. }\end{array}$ \\
\hline
\end{tabular}

Background: The development of human resources for eye health $(\mathrm{HReH})$, aimed at achieving a $25 \%$ reduction in visual impairment by the year 2020, was one of the VISION 2020 objectives.

Aim: To assess HReH in the public sector of KwaZulu-Natal (KZN), and its effect on the accessibility of eye care in the province.

Setting: All public eye facilities in KZN.

Methods: A quantitative cross-sectional study using a close-ended questionnaire to assess distribution and outputs of $\mathrm{HReH}$. At the end of the questionnaire, respondents gave general comments on their ability to provide services.

Results: Human resource rates were 0.89 for ophthalmologists, 2.44 for cataract surgeons, 4.8 for optometrists and 4.7 for ophthalmic nurses per 1 million population. Most health facilities had some $\mathrm{HReH}$ working in them, albeit none had dispensing opticians. Regression analysis showed that $67.1 \%$ of variation in cataract surgery was because of the number of surgeons available. Cataract surgical rates were low with a waiting period of up to 18 months. In addition to the refractive error regression analysis of $33.7 \%$, spectacle supply was low, with a backlog of up to 9 months in some facilities.

Conclusion: Overall, HReH targets as per VISION 2020 and the National Prevention of Blindness have not been met in this region. Dispensing opticians are not employed in any of the province's health districts. An increase in the eye health workforce is necessary to improve the eye health outcomes for people dependent on public eye facilities.

Keywords: human resources for eye health; public eye health services; visual impairment; KwaZulu-Natal, South Africa; eye care.

\section{Introduction}

Development and training of adequate human resources is a critical factor in the ongoing efforts to reduce visual impairment (VI) and avoidable blindness in many countries. Visual impairment and blindness contribute to a reduced quality of life, increased poverty and lowered educational and employment opportunities amongst the visually impaired. ${ }^{1}$ Adequate resource allocation can significantly reverse the impact of VI. Therefore, the World Health Organization (WHO) prioritised the number and geographical distribution of health workers in eye health in an effort to reduce VI globally. ${ }^{2}$ The WHO in partnership with the International Agency for the Prevention of Blindness (IAPB) established a joint initiative known as 'VISION 2020: the Right to Sight', aimed at addressing the challenges of avoidable blindness in the world. ${ }^{2,3,4,5}$ As a priority to make an impact, the need for the development of human resources for eye health (HReH) was prioritised amongst the VISION 2020 goals of reducing VI and blindness globally.

As over 405.1 million visually impaired and 36 million blind people globally age and live longer, the considerable burden of eye health continues to grow. ${ }^{6,7,8}$ Of great concern is the fact that $80 \%$ of avoidable blindness and VI are found in low-to-middle-income countries (LMICs), such as South Africa, that employ only $33 \%$ of the global health workforce. ${ }^{5}$

In an effort to prioritise eye health and secure access to rehabilitation for the visually impaired, the WHO developed the Global Action Plan (GAP), a strategy aimed at reducing VI by $25 \%$ by $2020 .{ }^{5}$ For this outcome to be achieved, the causes of VI needed to be noted so as to ensure that 
progress and impact of programmes targeting the reduction of avoidable VI could be measured. With cataracts and uncorrected refractive error (URE) being the main causes of VI and blindness globally, cataract surgical rate (CSR) and correction of refractive errors need to be prioritised as measurable outcomes. ${ }^{5}$ As ophthalmologists were the key $\mathrm{HReH}$ to perform eye surgery, optometrists were the main professionals for performing refractions and low vision services, and ophthalmic nurses for basic eye health treatment, $\mathrm{HReH}$ target ratios were primarily centred on these cadres. In light of these different roles, suggested $\mathrm{HReH}$ ratios in the eye care workforce would aim to mainly improve CSR and increase refraction and supply of visual assistive devices within different nations. As much as the suggested $\mathrm{HReH}$ ratios were meant to combat the two leading causes of VI and blindness, it was not clear how they would respond to prevention of chronic conditions linked to primary health care (PHC) and other serious ocular pathologies such as diabetic retinopathy and glaucoma. ${ }^{9}$

The VISION 2020 initiative proposed population based distibution ratios of 1:250000 for ophthalmologists and optometrists, and 1:100 000 for ophthalmic nurses. ${ }^{3}$ To adapt these for the local context, the South African National Guideline for prevention of blindness further enhanced these $\mathrm{HReH}$ requirements by aiming to place one primary eye health trained nurse in each community health centre (CHC) and at least one ophthalmologist or ophthalmic medical officer (OMO) per 1 million people. ${ }^{10}$

Studies in sub-Saharan Africa have shown that in many countries, the VISION 2020 targets of $\mathrm{HReH}$ are far from being met., ${ }^{5,10,11}$ National plans and programmes have made recommendations for the maintenance, regular training and retention of an efficient workforce, proportional to the populations of each country. It was further suggested that precise information in different countries should be collected to allow for specific $\mathrm{HReH}$ strategies to be custom designed for individual countries. This would also assist in further understanding the distribution of $\mathrm{HReH}$ who are generally concentrated in urban areas, leaving rural areas with a greater burden of disease. ${ }^{2,12}$

The Republic of South Africa (RSA) trains five eye health cadres: ophthalmologists, optometrists, ophthalmic nurses, dispensing opticians and OMOs, who each have a specific role to play in the prevention and management of blindness and VI. In its district health system (DHS), the South African public health system provides PHC services at three levels of care, in an effort to ensure delivery of comprehensive primary health services within each district. ${ }^{13}$ Local clinics are the first point of access, followed by Community Health Clinics (CHCs) who ultimately refer to district hospitals at the peak of the PHC level. Collectively, these facilities are providers of level 1 care. ${ }^{14}$
In this decentralised mode of care, district hospitals provide generalist support to clinics and $\mathrm{CHCs}$, as well as diagnostic, treatment and care services to the public. ${ }^{15}$ Optometrists and ophthalmic nurses are pivotal at the level of PHC, and these are the cadres most needed in healthcare facilities (HCFs) at this level. ${ }^{10}$ Regional hospitals receive referrals for specialist care from district hospitals, and provide level 2 care with ophthalmologists and OMOs. ${ }^{14,16}$ Where these cannot help, referral to provincial tertiary hospitals follows, as they have more specialists and provide level 3 care. The fourth and final level of care for specialised cases is received at centralised hospitals (e.g. Inkosi Albert Luthuli Central Hospital in Ethekwini), which work together with a specialised hospital (e.g. McCords Eye Hospital in Ethekwini) at the highest level of care. ${ }^{14}$

The skewed distribution of $\mathrm{HReH}$ means that over $80 \%$ of the key cadres, optometrists and ophthalmologists, serve the private sector in urban areas, with the larger public sector remaining with less than $20 \%$ of these practitioners. ${ }^{9,17,18}$ Consequently, local studies have shown that output of these cadres, cataract surgery and refraction rates, are behind the targeted goals in the public sector. ${ }^{19,20}$ No study has assessed and evaluated $\mathrm{HReH}$ progress towards the VISION 2020 goals in the KwaZulu-Natal (KZN) public sector to date.

This study was aimed at firstly evaluating the $\mathrm{HReH}$ availability and distribution in the public sector (in KZN), in relation to population sizes and VISION 2020 targets, as well as assessing their outputs as required in their roles.

\section{Methods}

KwaZulu-Natal is the third largest province in South Africa, with a $57 \%$ rural population where $92.9 \%$ of its inhabitants are estimated to be medically uninsured and reliant on either private funds or the public health sector for services. ${ }^{21,22}$ An estimated 33\% of the population in $\mathrm{KZN}$ is found in the metropolitan, leaving $67 \%$ in outlying areas. This quantitative study used a cross-sectional approach to collect data from its public sector level 1, level 2 and level 3 HCFs that were willing to participate in the study.

Because of the lack of information on the District Health Barometer 2017 and 2018 report, ${ }^{22}$ the principal investigator (PI) visited each of the 11 district offices in the province to establish which of its HCFs had eye clinics that could be directly accessed by the public. ${ }^{22}$ After obtaining this information and contacting the HCFs, a saturated sampling was utilised to include HCFs who were willing to participate in the study, bringing the total number of HCFs to 55. Forty-six level 1, eight level 2 and one level 3 hospitals satisfied the study's inclusion criteria. Referral facilities such as the quaternary hospital and the special eye hospital were excluded as they are referral 
centres that are already well-staffed by virtue of their classification.

After obtaining ethical approval (ref no. BE155/19) from the University of KwaZulu-Natal, eye clinic staff were informed about the aim and objectives of the study. Those who were willing to participate in the study gave written informed consent.

Data collection was conducted using a close-ended questionnaire, requiring Yes/No responses, that had a section for general comments in the end. This was administered by the PI or a trained research assistant (RA). Contents of the questionnaire included a demographics section, questions on the number of different eye health cadres working in each facility and distribution of $\mathrm{HReH}$ followed by questions that assessed the various service outputs (in the way of cataract surgery rates and spectacle supply) to establish the adequacy of the available workforce. The questionnaire was piloted on seven HReH employed in another province, after which it was modified and used for the study. Respondents included ophthalmologists, optometrists and ophthalmic nurses who had been employed as permanent members of staff for more than 6 months in a particular eye clinic. In each HCF, one $\mathrm{HReH}$ was the respondent who verified information with other colleagues wherever necessary.

Each question was asked by the PI or RA, and responses were captured immediately. At the end, the respondent and other HReH were given an opportunity to provide brief general comments on staffing and issues that affected their ability to carry out their duties within that eye clinic. Once the questionnaire had been completed, responses were saved and stored in the PI's password-protected computer. After the completion of the study, data were cleaned, coded and captured using the Statistical Package for the Social Sciences (SPSS) version 26, after which these were analysed using descriptive statistics.

\section{Ethical considerations}

Ethical clearance was obtained from the Biomedical Ethics Research Committee at the University of KwaZulu-Natal, with the reference BE 155/19. Voluntary participation, informed consent, confidentiality of participants' identities and all national and departmental ethical guidelines were adhered to in this study.

\section{Results}

Out of the $86 \mathrm{HCF}$ in KZN province, 55 had eye clinics and the rest either did not have eye clinics or were specialised facilities such as psychiatric hospitals, tuberculosis (TB) hospitals, and one was specifically an eye hospital that was a referral unit for the province. The only quaternary facility in the province was also excluded as it was a referral centre for different health disciplines in the province. It was not directly accessible to patients - one had to be referred by other hospitals to be admitted there.
Respondents from the HCFs comprised 26 men (47.3\%) and 29 women $(52.7 \%)$, whose clinical roles involved 39 optometrists (70.9\%), 15 ophthalmic nurses (27.3\%) and one ophthalmologist $(1.8 \%)$. Further to the supplied information by the respondents, general comments were given by those staff members who were in the clinic at the time of data collection, a total of three ophthalmologists, two OMOs, 12 optometrists and eight ophthalmic nurses gave their comments.

\section{Current HReH staffing and distribution within KwaZulu-Natal Department of Health}

Uneven distribution of $\mathrm{HReH}$ across the 11 districts of the province showed that optometrists were present in all districts, with most of them working in King Cetshwayo and Umkhanyakude, both rural KZN districts. The only metro district, Ethekwini, had only $4 \%$ of the province's optometrists in their employment, whilst most of the optometric posts in their level $1 \mathrm{HCF}$ remained unfilled. These institutions were each serviced by a non-governmental organisation (NGO) once a week. Ophthalmic nurses were present in all districts and the majority of them (10\%) were found in Umkhanyakude and Illembe. Harry Gwala HCFs only employed $2 \%$ of the province's ophthalmic nurses. Ophthalmic medical officers were largely based in a tertiary hospital in Umgungundlovu (52\%), whilst districts Harry Gwala, Umzinyathi, Uthukela and Zululand did not have any OMOs in their employment.

Within the different socio-economic areas, from the eight regional and provincial HCFs included, the majority of the province's ophthalmologists $(67 \%)$ worked in regional township hospitals, with most urban posts unfilled. Most (52\%) of the OMOs were in urban or small-town settings, most optometrists $(44 \%)$ were in rural settings, whilst the bulk of the available ophthalmic nurses were in small towns (35\%) and rural (37\%) HCFs as shown in Figure 1.

\section{Staffing needs analysis with regard to VISION 2020 and South Africa's National Guidelines for the Prevention of Blindness}

Tables 1 and 2 show the required and available $\mathrm{HReH}$ categories in relation to VISION 2020 and National Prevention of Blindness guidelines, respectively. The ophthalmologist rate is $0.89(22.5 \%)$, whilst ophthalmic nurses are currently $4.7(47.0 \%)$ of the required 10 per 1 million population. There is a severe shortage of OMOs, whilst ophthalmologists, optometrists and ophthalmic

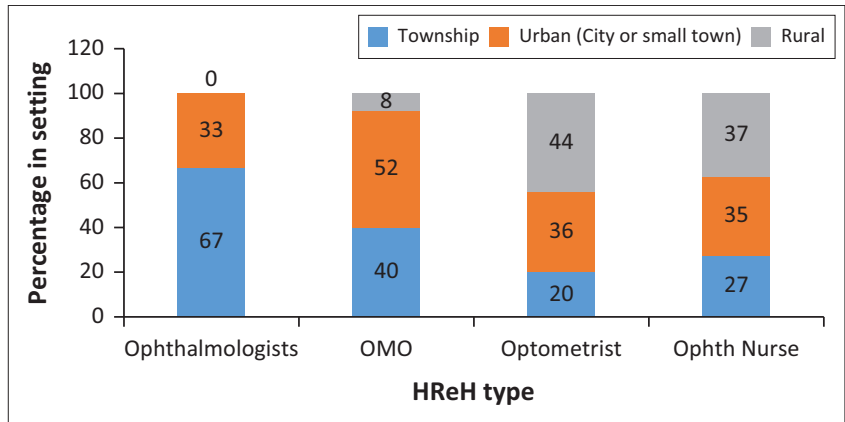

FIGURE 1: Distribution of human resources for eye health in different areas. 
TABLE 1: Staffing gap analysis in line with VISION 2020 which specifies staffing quotas in relation to population size.

\begin{tabular}{|c|c|c|c|c|}
\hline Human resource type & Need VISION 2020 & Available & $\begin{array}{c}\text { Ideal rate per } \\
1 \text { million population }\end{array}$ & $\begin{array}{c}\text { Actual rate per } \\
1 \text { million population }\end{array}$ \\
\hline Ophthalmologists & 41 & 9 & 4 & 0.89 \\
\hline Optometrists & 41 & 49 & 4 & 4.8 \\
\hline Ophthalmic nurses & 102 & 48 & 10 & 4.7 \\
\hline Opticians/Dispensers & $\mathrm{N} / \mathrm{S}$ & 0 & $\mathrm{~N} / \mathrm{S}$ & 0 \\
\hline OMO (including 2 that are also Medical Managers) & 41 & 25 & 10 & 2.44 \\
\hline Other nurses & $\mathrm{N} / \mathrm{S}$ & 39 & $\mathrm{~N} / \mathrm{S}$ & 0 \\
\hline Administration staff & $\mathrm{N} / \mathrm{S}$ & 4 & $\mathrm{~N} / \mathrm{S}$ & 0 \\
\hline Technicians & $\mathrm{N} / \mathrm{S}$ & 0 & $\mathrm{~N} / \mathrm{S}$ & 0 \\
\hline
\end{tabular}

$\mathrm{N} / \mathrm{S}$, Number not specified yet these staffing categories should be available to support services; $\mathrm{CHC}$, community health centre.

OMO, ophthalmic medical officer.

TABLE 2: Human resources for eye health needs analysis according to the National Prevention of Blindness RSA which categorises staffing according to healthcare facility (HCF) types/levels where surgeons are specified to practise mainly in level 3 (mainly ophthalmologists) and level 2 (mainly ophthalmic medical officer ) HCFs, optometrists in district hospitals and ophthalmic nurses in community health centre.

\begin{tabular}{|c|c|c|c|c|c|c|}
\hline \multirow[t]{2}{*}{ HReH type } & \multicolumn{2}{|c|}{$\begin{array}{c}\text { Tertiary hospital with } \\
\text { HReH ( } 9 \text { in total) }\end{array}$} & \multicolumn{2}{|c|}{$\begin{array}{l}\text { District hospitals with } \\
\text { HReH (33 in total) }\end{array}$} & \multicolumn{2}{|c|}{$\begin{array}{l}\text { CHC clinics with } \mathrm{HReH} \\
\text { (13 in total) }\end{array}$} \\
\hline & Need & Available & Need & Available & Need & Available \\
\hline \multirow[t]{2}{*}{ Ophthalmologists } & 9 & 5 (short of 4 ) & $N / S$ & $\mathrm{~N} / \mathrm{S}$ & $\mathrm{N} / \mathrm{S}$ & $N / S$ \\
\hline & & $55 \%$ achieved & & & & \\
\hline \multirow[t]{2}{*}{ Optometrists } & $N / S$ & 15 & 33 & 22 (short of 11 ) & $\mathrm{N} / \mathrm{S}$ & 6 \\
\hline & & & & $66 \%$ achieved & & \\
\hline \multirow[t]{2}{*}{ Ophthalmic nurses } & $N / S$ & 14 & $\mathrm{~N} / \mathrm{S}$ & 31 & 13 & 7 (short of 6) \\
\hline & & & & & & $53 \%$ achieved \\
\hline OMO & $\mathrm{N} / \mathrm{S}$ & 23 & $\mathrm{~N} / \mathrm{S}$ & 1 & $\mathrm{~N} / \mathrm{S}$ & \\
\hline
\end{tabular}

$\mathrm{N} / \mathrm{S}$, Number not specified yet these staffing categories should be available to support services.

$\mathrm{HReH}$, human resources for eye health; $\mathrm{OMO}$, ophthalmic medical officer; $\mathrm{CHC}$, community health centre.

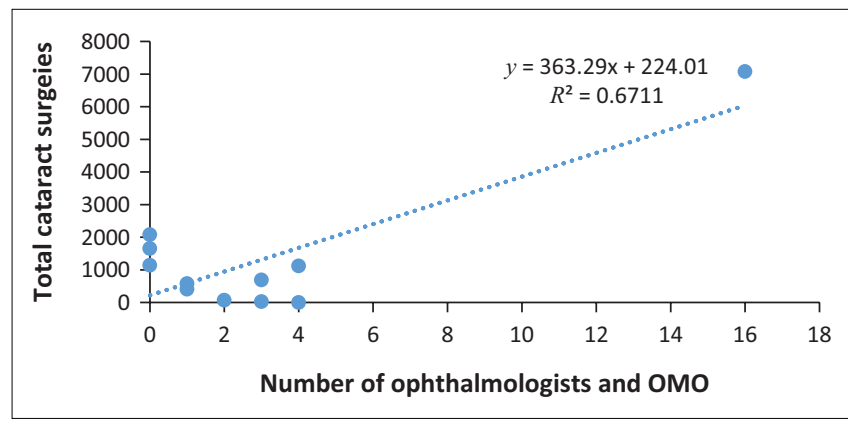

OMO, ophthalmic medical officer.

FIGURE 2: Regression analysis of total cataract surgeries versus number of available surgeons.

nurses have achieved 55\%, 66\% and 53\% in terms of staffing placement in the province's HCFs. Other support staff such as administrators and other nurses are still under-supplied, and there are no technicians employed to support eye health services in KZN.

\section{Output because of available human resources for eye health in the province}

To measure the impact on prevention of blindness, ophthalmologist and OMOs are responsible for cataract surgeries in the province, whilst optometrists attend to URE mainly.

\section{Cataract surgeries}

These surgeries performed in the included institutions were highest (2075) in Umgungundlovu, where there is a level 3 hospital with a high number of surgeons, and lowest in outlying rural districts - Zululand, Harry Gwala and
Umzinyathi that refer cataract cases to higher level hospitals. Overall, CSR for the province was 73\%.

Regression analysis, in Figure 2, for CSR found $R^{2}$ to be 0.67, showing that $67 \%$ of the cataract operations performed were as a result of available surgeons. The $33 \%$ underperformance is most probably because of a shortage of surgeons to perform operations, lack of equipment, a shortage of lens stock and lack of adequate theatre space. Visiting NGOs supplemented the Department by operating at cataract removal camps at various outlying hospitals in Harry Gwala district, Umzinyathi district and others.

\section{Uncorrected refractive error}

Table 3 shows that most refractions were performed in King Cetshwayo and Umkhanyakude, the districts with the highest number of optometrists. Harry Gwala, with only two optometrists, performed the least number of refractions in the province.

Regression analysis of refractive error in Figure 3 shows that approximately $24 \%$ of the spectacle correction is because of the number of optometrists employed in the province.

The shortfall of $76 \%$ is likely to be because of the shortage of equipment, inadequate number of optometrists, the lack of dispensing opticians and the lack of a spectacle supplier and clear supply chain in the province as a whole. 


\section{General comments by respondents}

Table 4 indicates general comments made by the respondents as grouped by professional categories.

\section{Discussion}

KwaZulu-Natal is the third largest province in South Africa, with a population of 11.1 million. ${ }^{23}$ It is largely a rural province, with the densely populated Ethekwini district municipality

TABLE 3: A breakdown of cataract surgeries and refractions performed.

\begin{tabular}{lcccc}
\hline District & $\begin{array}{c}\text { Number of } \\
\text { surgeons }\end{array}$ & $\begin{array}{c}\text { Cataract } \\
\text { surgeries/years }\end{array}$ & $\begin{array}{c}\text { Number of } \\
\text { Optometrists }\end{array}$ & $\begin{array}{c}\text { Refractions } \\
\text { performed }\end{array}$ \\
\hline Amajuba & 4 & 1117 & 7 & 749 \\
Ethekwini & 3 & 1162 & 2 & 2245 \\
Harry Gwala & 0 & 26 & 2 & 337 \\
Illembe & 4 & 574 & 5 & 2536 \\
King Cetshwayo & 3 & 1653 & 8 & 4525 \\
Ugu & 2 & 1137 & 4 & 3823 \\
Umgungundlovu & 15 & 2075 & 5 & 3830 \\
Umkhanyakude & 1 & 687 & 8 & 4116 \\
Umzinyathi & 0 & 65 & 6 & 3087 \\
Uthukela & 1 & 404 & 4 & 3574 \\
Zululand & 0 & 0 & 3 & 1696 \\
\hline
\end{tabular}

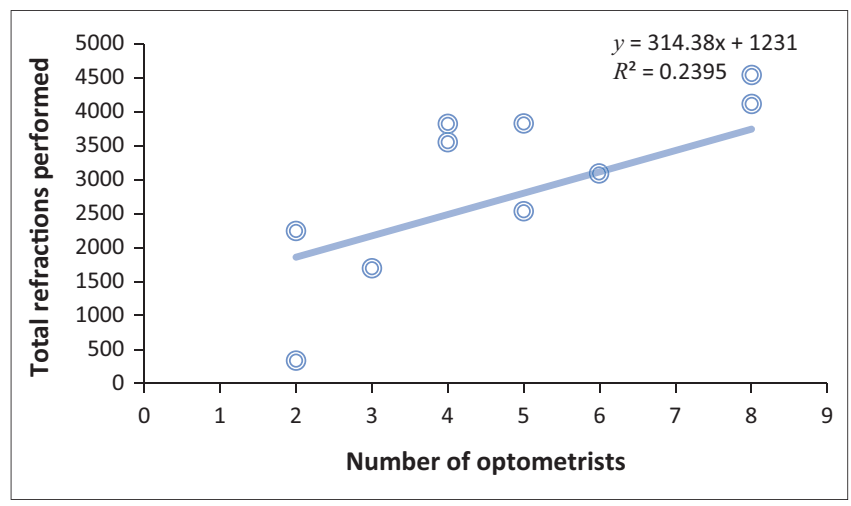

FIGURE 3: Regression analysis of total refractions performed by optometrists in KwaZulu-Natal. being the economical hub of the province. ${ }^{22}$ Its rating as a Quintile 5 municipality means that it is graded as one of the wealthiest districts in the country on the scale of 1 (poorest) to 5 (wealthiest). Furthermore, 25 of the 55 HCFs in KZN are in the Ethekwini district, including the province's only public eye hospital (McCords) and quaternary hospital (Inkosi Albert Luthuli Central Hospital), both of which serve as referral facilities for the whole province. ${ }^{24}$ The province's poorest (Quintile 1) municipalities are Harry Gwala, Umkhanyakude, Umzinyathi, UThukela and Zululand. ${ }^{22,23}$ Each district in the province offers health services through HCFs that are equipped with eye clinics and staffed with $\mathrm{HReH}$ that seek to provide eye health services within those districts.

This study aimed to identify the different types of $\mathrm{HReH}$ within KZN's public sector, and how this related to the provision of eye health services in the region. The WHO suggested that human resources rates should be 4,4 and 10 per 1 million population for ophthalmologists, optometrists and ophthalmic nurses, respectively. ${ }^{25}$ Similar to regions in Nigeria, Ghana and other countries in sub-Saharan Africa, KZN has not entirely met the suggested HReH targets at the end of 2019.9,26,27 The number of optometrists has met the VISION 2020: Right to Sight target; however, it has fallen short of the National Prevention of Blindness requirements, which look at distribution applicable to the DHS in South Africa.

The study found that there was an uneven distribution of eye care personnel, with many optometrists and ophthalmic nurses concentrated in urban health facilities. This result is similar to that of Thivhafuni, who reported that the HCFs did not have any optometrists in under-resourced areas (townships and rural areas) of Limpopo province of South Africa. ${ }^{27}$ Similar results have been reported in other developing countries such as Nigeria and Ghana. ${ }^{18,29}$ The unequal distribution of eye care personnel exacerbates the burden of eye diseases in poor communities.

TABLE 4: The main themes that were identified as general comments by various types of human resources for eye health that were present in the eye clinic during data collection.

\begin{tabular}{|c|c|c|c|c|}
\hline HReH category & Shortage of equipment & Increased workloads & Shortage of other resources & Training and other matters \\
\hline Optometrists (3) & $\begin{array}{l}\text { - Old obsolete equipment hinders } \\
\text { theatre work }\end{array}$ & $\begin{array}{l}\text { - Over-referrals, optometrists } \\
\text { with expanded scope should } \\
\text { deal with some cases } \\
\text { - Lack of administration staff }\end{array}$ & $\begin{array}{l}\text { - Shortage of surgeons negatively } \\
\text { impacts service delivery }\end{array}$ & $\begin{array}{l}\text { - Eye health is not a priority so it is } \\
\text { poorly resourced }\end{array}$ \\
\hline Optometrists (12) & $\begin{array}{l}\text { There is a severe shortage of } \\
\text { basic equipments: tonometers, } \\
\text { trial frames and trial cases and } \\
\text { visual acuity charts }\end{array}$ & $\begin{array}{l}\text { - There is a shortage in staffing. } \\
\text { Working in more than one } \\
\text { hospital and being unable to do } \\
\text { outreach is a great disadvantage }\end{array}$ & $\begin{array}{l}\text { - The spectacle supply chain is } \\
\text { currently dysfunctional. Some } \\
\text { optometrists have not dispensed } \\
\text { spectacles in } 9 \text { months. }\end{array}$ & $\begin{array}{l}\text { - More Optometrists need } \\
\text { therapeutics training } \\
\text { - Lack of career progression and a } \\
\text { clear career pathway is demotivating } \\
\text { - Screening and other blindness } \\
\text { prevention work is retarded by their } \\
\text { only being one optometrist in the HCF }\end{array}$ \\
\hline Ophthalmic nurses (8) & - Basic equipment is lacking & $\begin{array}{l}\text { - Where there is no optometrist, } \\
\text { the Ophthalmic Nurse ends up } \\
\text { working in a few departments }\end{array}$ & $\begin{array}{l}\text { - Vacant optometry posts retard } \\
\text { work output and lower the value } \\
\text { added by the eye clinic. } \\
\text { - Lack of spectacle supplier is a major } \\
\text { problem }\end{array}$ & $\begin{array}{l}\text { - Eye clinic is shut down completely } \\
\text { when the nurse goes on outreach } \\
\text { or is on leave when there is no } \\
\text { optometrist. } \\
\text { - Eye health not prioritised when } \\
\text { there is no other HReH so } \\
\text { Ophthalmic Nurses are taken to } \\
\text { work in other priority departments }\end{array}$ \\
\hline
\end{tabular}

HCF, healthcare facilities; HReH, human resources for eye health; OMO, ophthalmic medical officer; CSR, cataract surgical rate. 
Refractive services in five township HCFs were rendered a few days in a month by an NGO, which was also the sole spectacle supplier to patients in the province. In the other two townships, there were no eye care services as there were no $\mathrm{HReH}$ employed, further impacting the progress of reducing VI in some areas. Refractive services in the remaining few rural HCFs were provided by visiting optometrists employed by the district offices of the Department of Health. As most of these institutions had only ophthalmic nurses, refractive cases, low vision cases and cataract extraction patients were referred to regional hospitals. With refractive errors reported to be one of the leading causes of VI worldwide, ${ }^{28}$ it is inadequate for any public health system to underservice this need by not providing enough optometrists to address this problem. Previous studies in Nigeria, Ghana and Zambia have reported the lack of eye health professionals in lower socioeconomic areas. ${ }^{26,29}$ To capacitate for the shortage of $\mathrm{HReH}$, other areas have tried immediately sequential bilateral cataract surgery to accelerate CSR. ${ }^{30}$ Countries such as India have incorporated telemedicine, ${ }^{31}$ whilst others have expanded the scope of practice in existing cadres to ensure service availability. Zambia, for example, has expanded the scope of practice for ophthalmic nurses by providing them training to perform cataract surgeries to accelerate CSR in underserviced areas which have no cataract surgeons. ${ }^{11}$ Similarly, refractionists were trained in refraction to relieve the backlog of URE in countries with no optometrists. ${ }^{9}$ Human resources for eye health should be planned according to the epidemiology of eye conditions to address diagnosis and treatment, as well as to reduce avoidable causes of VI.

Considering that townships are generally low-income areas, specifically left for habitation by non-white citizens during the apartheid era in South Africa, ${ }^{21}$ it is encouraging to see that the regional hospitals in these areas have most of the appropriate eye health cadres. Previous studies have found that most of the $\mathrm{HReH}$ workforce located in urban areas and rural areas remain under-resourced. ${ }^{22,33,34}$ As townships are semi-urban, these hospitals may be better resourced because they are easily accessible to urban areas.
It is also possible that these hospitals in townships and rural areas are better staffed with OMOs, ophthalmologists and nurses because of the fact that these cadres are offered retention packages including rural allowances, which optometrists do not get. ${ }^{35}$

Of concern is the Ethekwini region, the largest district in KZN, which had the highest shortage of $\mathrm{HReH}$ in the province (Table 5). There are few ophthalmic nurses, most of whom were working in the eye clinics by themselves. In such instances, there were minimal outreach programmes from these institutions. Outreach services include vision screening, eye health promotion and prevention of eye diseases, which aim to promote preventative eye healthcare. ${ }^{36}$ The lack of adequate $\mathrm{HReH}$ is an impediment to service delivery as the population that is being served requires such services. Because of $\mathrm{HReH}$ shortages in under-resourced areas, patients cannot be screened for early visual problems detection and management. As a result, these patients suffer from avoidable conditions such as refractive error, which has a high prevalence in South African schoolgoing children,,$^{37,38}$ and diabetic retinopathy and glaucoma, which are more common in the elderly population. Cataract cases are easier to detect, and these are referred accurately albeit delayed through a bottleneck effect because of the low number of ophthalmologists and OMOs. Unavailability of transport further delays the referrals to regional hospitals.

The lack of attention to eye care ultimately and provision of resources results in patients being uncertain of whether or not services are available. The challenge of eye health not being prioritised in South Africa has previously been expressed by Lecuona, Thivhafuni and Sithole in other parts of the country. ${ }^{19,20,39}$ Sithole suggested that this could be because of the lack of dedicated directorate for eye health as eye health falls under the guidelines of non-communicable diseases in the health directorate. ${ }^{36}$ A possible solution would be for the Department of Health to consider appointing an eye health director to oversee this area of health in order to fulfil programmes and targets for improved outputs in eye care services.

TABLE 5: A summary of staffing within the KwaZulu-Natal health facilities showing population size, hospital types and human resources for eye health across the province.

\begin{tabular}{|c|c|c|c|c|c|c|c|c|c|}
\hline District & $\begin{array}{l}\text { Socio-economic } \\
\text { quintile }\end{array}$ & $\begin{array}{l}\text { Uninsured } \\
\text { population }\end{array}$ & $\begin{array}{l}\text { Level } 1 \\
\text { HCF }\end{array}$ & $\begin{array}{c}\text { Optometrists } \\
(N)\end{array}$ & $\begin{array}{c}\text { Level } 2 \\
\text { HCF }\end{array}$ & OMOs $(N)$ & $\begin{array}{c}\text { Level } 3 \\
\text { HCF }\end{array}$ & $\begin{array}{c}\text { Ophthal- } \\
\text { mologists }(N)\end{array}$ & $\begin{array}{c}\text { Ophthalmic } \\
\text { nurses }(N)\end{array}$ \\
\hline Amajuba & 3 & 510178 & 3 & 7 & 1 & 3 & 0 & 1 & 2 \\
\hline Ethekwini & 5 & 2989153 & 6 & 2 & 1 & 2 & 0 & 1 & 5 \\
\hline Harry Gwala & 1 & 469908 & 4 & 2 & 0 & 0 & 0 & 0 & 1 \\
\hline Illembe & 2 & 629157 & 4 & 5 & 1 & 3 & 0 & 1 & 10 \\
\hline King Cetshwayo & 2 & 883909 & 6 & 8 & 1 & 0 & 0 & 3 & 5 \\
\hline Umgungundlovu & 3 & 989141 & 4 & 5 & 1 & 13 & 1 & 2 & 5 \\
\hline Umkhanyakude & 1 & 648763 & 6 & 8 & 0 & 1 & 0 & 0 & 5 \\
\hline Umzinyathi & 1 & 524378 & 5 & 6 & 0 & 0 & 0 & 0 & 5 \\
\hline Uthukela & 1 & 687956 & 2 & 4 & 1 & 1 & 0 & 0 & 2 \\
\hline Zululand & 1 & 806554 & 5 & 3 & 0 & 0 & 0 & 0 & 3 \\
\hline
\end{tabular}

OMO, ophthalmic medical officer; HCF, healthcare facility. 
The WHO has recently suggested the inclusion of allied ophthalmic personnel as part of the solution in alleviating the shortage of $\mathrm{HReH}$ in most rural areas as they are readily available. ${ }^{4}$ This mid-level group of eye care personnel would include dispensing opticians, who are locally trained and not used within the public sector, and ophthalmic photographers, who could be instrumental in tele-ophthalmology, as well as ophthalmic technicians, who could assist ophthalmologists in theatres. ${ }^{40}$

Further investigations are required to determine the reasons for the existing shortage of $\mathrm{HReH}$ in this province. Furthermore, the availability of resources needed for $\mathrm{HReH}$ to perform their duties is another area that should be explored to improve the current situation. The shortage of ophthalmologists to perform surgical procedures results in unmet outputs on CSR. The required human resources for refractive services are not adequate and are unevenly distributed between rural and urban areas of the province.

\section{Conclusion}

The numbers of available $\mathrm{HReH}$ in $\mathrm{KZN}$ did not meet the required targets. Similarly, the required numbers of $\mathrm{HReH}$ in the province were not met in 2020, negatively impacting the target of achieving a $25 \%$ reduction in VI and avoidable blindness. The provincial KZN government should prioritise eye health and increase HReH. Dispensing opticians should also be employed to positively impact spectacle production and supply which is a key factor in the reduction of VI because of RE. An increase in the eye workforce will have a positive impact in the fight against VI and avoidable blindness.

\section{Acknowledgements}

The authors thank the directorate and eye health workers who participated in this study.

\section{Competing interests}

The authors declare that they have no financial or personal relationships that may have inappropriately influenced them in writing this article.

\section{Authors' contributions}

Z.N.X. conceptualised the study and prepared the manuscript. K.P.M. and K.S.N. supervised the study and contributed to the final version of the manuscript.

\section{Funding information}

The authors thank the UKZN University Capacity Development Programme for funding this study.

\section{Data availability}

Data sharing is not applicable to this article.

\section{Disclaimer}

The views and opinions expressed in this article are those of the authors and do not necessarily reflect the official policy or position of any affiliated agency of the authors.

\section{References}

1. Jaggernath J, Øverland L, Ramson P, Vilas Kovai V, Chan VF, Naidoo KS. Poverty and eye health. Sci Res. 2014;6:1849-1860. https://doi.org/10.4236/health. 2014.614217

2. VISION 2020. Global human resource development assessment for comprehensive eye care. Vision 2020: The right to sight: Human Resource Development Working Group [homepage on the Internet]. Pakistan Institute of Community Ophthalmology; 2016 [cited 2019 Oct 28]. Available from: https://www.iapb.org/ wp-content/uploads/Global-HR-Development-Assessment-for-ComprehensiveEye-Care_2006.pdf

3. World Health Organisation. VISION 2020: The Right to Sight: Global Initiative for the Elimination of Avoidable Blindness Action Plan 2006-2011. Action Plan 2006-2011, ed. IAPB [homepage on the Intenet]. World Health Organisation 2007 [cited 2017 Oct 01]. Available from: www.who.int/blindness/Vision2020_ report.pdf

4. World Health Organisation. Core competencies for the eye health workforce in the WHO African Region [homepage on the Internet]. Brazzaville: WHO Regional Office for Africa; 2019 [cited 2019 Sept 28]. Available from: http://www.aho.afro. who.int/sites/default/files/publications/7681/Core $\% 20$ Competencies $\% 20$ for $\% 20$ Eye $\% 2$ HWF $\% 20$ in $\% 20$ WHO $\% 20$ AFRO $\% 2$ Region.pdf

5. World Health Organisation. Universal Eye Health: A Global Action Plan 2014-2019 [homepage on the Internet]. Geneva: World Health Organisation; 2013 [cited 2017 Oct 02]. Available from: https://www.iapb.org/advocacy/global-actionplan-2014-2019/

6. Bourne R, Flaxman S, Braithwaite T, McKee M. Magnitude, temporal trends, and projections of the global prevalence of blindness and distance and near vision impairment: A systematic review and meta-analysis. Lancet Glob Health. 2017;5(9):e888-e897. https://doi.org/10.1016/S2214-109X(17)30293-0

7. Rechel B, Doyle Y, Grundy E, McKee M. How can health systems respond to population ageing? Health systems and policy analysis [homepage on the
Internet]. 2009 [cited 2020 Feb 20]. Available from: https://www.euro.who.int/ Internet]. 2009 [cited 2020 Feb 20]. Available from: https://www.euro.who.int/
en/health-topics/Life-stages/healthy-ageing/publications/2009/how-can-healthsystems-respond-to-population-ageing

8. United Nations. World population ageing 2013 [homepage on the Internet]. New York, NY: United Nations; 2013 [cited 2018 May 19]. Available from: https://www.
un.org/en/development/desa/population/publications/ageing/ un.org/en/development/d
WorldPopulationAgeing2013.asp

9. Palmer J, Chinanayi F, Gilbert A, et al. Mapping human resources for eye health in 21 countries of sub-Saharan Africa: Current progress towards VISION 2020. Hum Resour Health [serial online]. 2014 [cited 2018 Jun 22];12:44. Available from: hesour Health [serial online]. 2014 [cited 2018 Jun 22];12:44. Available from: https://www.nch
4491-12-44.pdf

10. Department of Health. National guideline: Prevention of blindness in South Africa, ed. D.a.G. Directorate: Chronic Diseases [homepage on the Internet]. Pretoria; 2002 [cited 2018 Jan 02]. Available from: https://www.westerncape.gov.za/ text/2003/eye2.pdf

11. Bozzani F, Griffiths U, Blanchet K, Schmidt E. Health systems analysis of eye care services in Zambia: Evaluating progress towards VISION 2020 goals. BMC Health Serv Res [serial online]. 2014 [cited 2019 Jan 2];14:94. Available from: https://www.ncbi.nlm.nih.gov/pmc/articles/PMC3942069/pdf/1472-6963-1494tps://f

12. Odusote K. People deliver eye care: Managing human resources. Community Eye Health [serial online]. 2005 [cited 2019 Sept 8]:18(56):117-119. Available from: https://www.ncbi.nlm.nih.gov/pmc/articles/PMC1705692/pdf/jceh_18_56_117.pdf

13. Barron P, Asia B. The district health system. S Afr Health Rev [serial online]. 2001 [2021 Jan 12];2001(1):17-48. Available from: https://journals.co.za/content/ healthr/2001/1/EJC35367

14. KwaZulu-Natal Department of Health. Referral system: Levels of health care [homepage on the Internet]. 2014 [cited 2021 Mar 28]. Available from: http:// www.kznhealth.gov.za/Referral-system.htm

15. Department of Health - Pretoria. A District Hospital Service Package for South Africa [homepage on the Internet]. 2002 [cited 2019 May 02] Available from: https://pdf4pro.com/view/a-district-hospital-service-packagefor-south-africa-2a1f76.html

16. Verma R, Khanna P, Prinja S, Rajput M, Arora V. The National programme for control of blindness in India. Aust Med J. 2011;4(1):1-3. https://doi.org/10.4066/ AMJ.2011.50

17. Mashige KP, Naidoo KS. Optometric practices and practitioners in KwaZulu-Natal, South Africa*. Afr Vision Eye Health. 2010;69(2):77-85. https://doi.org/10.4102/ aveh.v69i2.128

18. Hong H, Mújica O, Anaya J, Lansingh VC, López E, Silva JC. The challenge of universal eye health in Latin America: Distributive inequality of ophthalmologists in 14 countries. BMJ Open. 2016;6(11):e012819. https://doi.org/10.1136/ bmjopen-2016-012819

19. Lecuona K. Analysis of eye care services in South Africa's public sector. Community Eye Health [serial online]. 2007 [cited 2018 May 12];20(64):72. Available from: https://www.ncbi.nlm.nih.gov/pubmed/18330445 
20. Lecuona K, Cook C. South Africa's cataract surgery rates: Why are we not meeting our targets? S Afr Med J [serial online]. 2011 [cited 2018 Sept 22];101(8):510-512. our targets? ? Available from: http://www.scielo.org.za/scielo.php?script=sci_arttext\&pid Available from: http://w

21. Prinsloo DA. Urbanisation and the impact on future shopping centre development in Africa and South Africa [homepage on the Internet]. South African Council for wp- content/uploads/2016/07/2662-SAC-Urbanisation-Report-Sept-2014-T3-2.pdf

22. Massyn N, Tanna G, Day C, et al. District health barometer: District Health Profiles 2017/18 [homepage on the Internet]. Durban: Health Systems Trust; 2018 [cited 2018 Dec 12]. Available from: https://www.hst.org.za/publications/District $\% 20$ Health\%20Barometers/DHB+2017-18+Web+8+Apr+2019.pdf

23. Department of Statistics South Africa. Improving lives through data ecosystems. Category Archives: Population characteristics 2020 [homepage on the Internet] [cited 2020 Jan 04]. Available from: http://www.statssa.gov.za/?cat=15

24. KZN Department of Health. KwaZulu-Natal Province Health [homepage on the Internet]. 2021 [cited 2021 Mar 28]. Available from: http://www.kznhealth.gov.za/

25. World Health Organisation. Health workers: A global profile [homepage on the Internet]. Geneva: World Health Organisation; 2006a [cited 2019 Feb 10] Available from: https://www.who.int/whr/2006/chapter1/en/

26. Merepa $S$, Akowuah $P$, Abazele $A$, et al. An assessment of the human resource in eye care in the Upper East Region, Ghana. Adv Ophthalmol Vis Syst [serial online]. 2017 [cited 2018 Jan 02];7(6):00245. Available from: https://medcraveonline. com/AOVS/an-assessment-of-the-human-resource-in-eye-care-in-the-uppereast-region-ghana.html

27. Eze B, Maduka-Okafor F. An assessment of the eye care workforce in Enugu State south-eastern Nigeria. Hum Resour Health [serial online]. 2009 [cited 2018 Feb 02];7:38. Available from: https://www.ncbi.nlm.nih.gov/pmc/articles/ PMC2688478/pdf/1478-4491-7-38.pdf

28. Courtright P, Mathenge W, Kello AB, Cook C, Kalua K, Lewallen S. Setting targets for human resources for eye health in sub-Saharan Africa: What evidence should be human resources for eye health in sub-Saharan Africa: What evidence should be
used? Hum Resour Health. 2016;14:11. https://doi.org/10.1186/s12960-016used?

29. Tey N, Lai S. Correlates of and barriers to the utilization of jealth services for delivery in South Asia and sub-Saharan Africa Hindawi Publishing Corporation. Sci World J. 2013;2013(423403):11. https://doi.org/10.1155/2013/423403

30. Moti FR. Immediately sequential bilateral cataract surgery: A possible solution for public sector cataract backlogs. S Afr Ophthalmol J [serial online]. 2019 [cited 2018 Jul 17];14(4):23-26. Available from: https://journals.co.za/content/ journal/10520/EJC-1ae6f03864
31. John S, Sengupta S, Reddy S, Prabhu P, Kirubanandan K, Badrinath SS. The Sankara Nethralaya mobile teleophthalmology model for comprehensive eye care delivery in rural India. Telemed J E Health. 2012;18(5):382-387. https://doi.org/10.1089/ tmj.2011.0190

32. Naidoo K, Holden B, Sweeney D, Colvin M. Design of a blindness prevention reporting and planning tool utilising the results of a population based study of visual impairment in a Health District in Kwazulu-Natal. Investig Ophthalmol Vis Sci. 2007;48(13):327-327.

33. Palmer J, Chinanayi F, Gilbert A, et al. Trends and implications for achieving VISION 2020 human resources for eye health targets in 16 countries of sub-Saharan Africa by the year 2020. Hum Resour Health [serial online]. 2014 [cited 2018 Jun 25];12:45. Available from: https://www.ncbi.nlm.nih.gov/pmc/articles/ 25];12:45. Available from: https:/
PMC4237790/pdf/1478-4491-12-45.pdf

34. Bogunjoko TJ, Hassan AO, Akanbi TB, Ashaye AS, Akinye AA. Analysis of human resources for eye health in Ogun State of Nigeria: Progress towards vision 2020. Br J Med Med Res. 2017;19(10):1-9. https://doi.org/10.9734/BJMMR/ 2017/31702

35. Public Health and Welfare Sector Bargaining Council. Revised non-pensionable recruitment allowance, referred to as "the rural allowance": Public sector health professionals working in hospitals/institutions as managed by the health employer [homepage on the Internet]. 2004 [cited 2021 Mar 15]. Available from: http:// rhap.org.za/wp-content/uploads/2014/05/Rural-Allowance-Public-Health-andrhap.org.za/wp-content/uploads/2014/05/Rural-Allowance-Pub
Welfare-Sector- Barganing-Council-Resolution-No.-2-of-2004.pdf

36. Sithole HL. A situational analysis of ocular health promotion in the South African primary health-care system. Clin Exp Optometry. 2017;100(2):167-173. https:// doi.org/10.1111/cxo.12452

37. Magakwe T, Xulu-Kasaba Z, Hansraj R. Prevalence and distribution of visual impairment and refractive error amongst school-going children aged 6-18 years in Sekhukhune District (Limpopo, South Africa). Afr Vision Eye Health. 2020;79(1): a551. https://doi.org/10.4102/aveh.v79i1.551

38. Wajuihian S, Hansraj R. Refractive error in a sample of black high school children in South Africa. Optom Vis Sci [serial online]. 2017 [cited 2019 Dec 12];94(12):1145-1152. Available from: https://pubmed.ncbi.nlm.nih. gov/29120975/

39. Sithole HL. Ecological considerations for intervention strategy in the development of eye health promotion policy in South Africa. Afr Vision Eye Health. 2015;74(1): a314. https://doi.org/10.4102/aveh.v74i1.314

40. American Academy of Ophthalmology. The Eye Care Team [homepage on the Internet]. 2019 [cited 2019 Nov 14]. Available from: https://www.aao.org/about/ eye-care-team 